\title{
Discurso paulista de modernidade e o museu: Yolanda Penteado, dos salões de arte aos museus regionais do nordeste (1903-1968)
}

\author{
Adel Igor Romanov Pausini ${ }^{1}$
}

\begin{abstract}
Na Paris do século XIX, era hábito comum entre os aristocratas a promoção de encontros entre pessoas de alta condição social com grupos da intelectualidade para concertos, espetáculos, bailes, tertúlias e demais eventos de salão em ambiente residencial. No Brasil, os salões ganham força no segundo reinado, sobretudo na capital do Império, estendendo o seu prestígio à florescente São Paulo do café no final do século XIX, tornando-se uma autêntica instituição da Belle Époque, tendo como os mais prestigiados os salões de Veridiana da Silva Prado, José de Freitas Valle, Paulo Prado e Olívia Guedes Penteado. Nestes espaços, a aristocracia paulista consolidava o capital social utilizado, o mecenato e a ação pública e privada para a promoção dos próprios interesses, projetos e perspectivas do país. Na década de 1930, os salões perdem força em detrimento da organização de sociedades e grupos de artistas, o que produz, em alguns casos, relativa independência em relação ao mecenato público e privado, permitindo o avanço de experiências de tendências anarquistas e comunistas, rapidamente revertidas enquanto plano hipotético na década de 1940 com a abertura dos grandes museus e eventos de arte em São Paulo, a internacionalização da arte e o financiamento norte-americano, em contexto de Guerra Fria. O êxito do projeto paulista, capitalista, urbano-industrial de museus é levado pela velha aristocracia, ressignificada e financiada pelo capital industrial emergente para outras regiões do país em pleno contexto nacional do regime militar de desenvolver e integrar.

Por meio do mecenato exercido de distintos modos, a aristocracia paulista defendeu e implementou, em alguma medida, o seu projeto de modernização conservadora no século XIX e XX, defendendo os seus interesses por meio dos salões e dos museus de arte.
\end{abstract}

Palavras Chave: Modernidade, Salões, Museu, Mecenato, Aristocracia paulista.

\footnotetext{
${ }^{1}$ Mestre em História Social (USP/2012) e em Ciências Sociais (PUC-SP/ 2014). Doutorando do Programa Interuniversitário em história da Universidade de Lisboa, Universidade de Évora, Universidade Católica Portuguesa e Instituto Universitário de Lisboa. Pesquisador doutoral do departamento de Museologia da Universidade Lusófona de Humanidades e Tecnologias. Financiamento ULHT (Portugal). Pesquisa em Andamento. E-mail: adel.igor@hotmail.com ou adel.pausini@ics.ulisboa.pt
} 


\title{
Paulista Speech of Modernity and the Museum: Yolanda Penteado, from salons of art to regional museums of Northeast Brazil (1903-1968)
}

\author{
Adel Igor Romanov Pausini ${ }^{2}$
}

In $19^{\text {th }}$ century Paris, it was an ordinary habit among aristocrats the fostering of meetings between people of high social status with intellectuality groups to concerts, performances, dance, literary assembly and other salon events in a residential environment. In Brazil, the salons began assuming greater power in the second reign, mainly in the capital of the Empire, expanding its prestige to the thriving São Paulo, known as the city of coffee in the end of $19^{\text {th }}$ century, becoming an authentic institution from Belle Époque, having Veridiana da Silva Prado's, José de Freitas Valle's, Paulo Prado's and Olivia Guedes Penteado's salons as the most prestigious ones. In these spaces, the Paulista aristocracy strengthened the capital stock, the patronage and the public and private action to foster their own interests, projects and the country's prospects. In the 1930s, the salons lost their strength to the detriment of the organization of societies and groups of artists which bring forth relative independence from public and private patronage in some cases, allowing the advance of experiences of anarchist and communist tendencies, quickly reversed as a hypothetical plan in the 1940s with the opening of the greatest museums and art events in São Paulo, the internationalization of art and the US funds, in the context of Cold War. The success of the urban-industrial capitalist Paulista project of museums is run by the old aristocracy, reframed and funded by emerging industrial capital to the other regions of the country in the full military regime context of developing and integrating.

Through the patronage exercised in different paths, the Paulista aristocracy somewhat defended and initiated its conservative modernization project in $19^{\text {th }}$ and $20^{\text {th }}$ century, defending its interests through the salons and museums of art.

Keywords: Modernity, Salons, Museum, Patronage, Paulista aristocracy.

\footnotetext{
${ }^{2}$ Doctoral candidate in the Inter-university Doctoral Program in History of University of Lisbon, University of Évora, Catholic University of Portugal and Technical Institute of Lisbon. Doctoral researcher from the Museology Department of Lusophone University of Humanities and Technology. Financing ULHT (Portugal). Ongoing research. E-mail: adel.igor@hotmail.com or adel.pausini@ics.ulisboa.pt
} 
Discurso paulista de modernidade e o museu: Yolanda Penteado, dos salões de arte aos museus regionais do nordeste (1903-1968)

A insignificante vila de São Paulo que em 1820 possuía apenas 6 mil habitantes em seu núcleo central tem sua realidade modificada em 1827, com a instalação da Academia de Direito no Largo São Francisco e com a expansão na lavoura cafeeira fluminense pelo interior paulista em meados da década de 1840. A junção destes dois fatores, academia e a formação intelectual dos principais quadros políticos do império ao lado de cidades como a própria corte e Olinda ${ }^{3}$, além do início da circulação de grande capital oriundo da riqueza agrícola, foram fatores determinantes para a reconfiguração e inserção em posição de prestígio de São Paulo no cenário político e econômico nacional.

Neste contexto, é formado um ciclo vicioso nos quadros da elite paulista, os quais pressupunha formação na Faculdade de direito do Largo São Francisco, envolvimento com a produção, exportação ou atividades comerciais e financeiras que orbitavam entorno do café e o envolvimento com as Companhias de estrada de ferro. No final do império, o projeto modernizante da família Silva Prado, um dos maiores produtores de café do estado, sobretudo para o conselheiro Antônio da Silva Prado, tinha por símbolo o aumento do número de imigrantes a trabalhar na lavoura cafeeira em substituição da mão de obra escrava e, por consequência, a abolição e o aumento do mercado consumidor, bem como a defesa da estabilidade política garantida pela monarquia. Para outro grupo de cafeicultores, entre eles Martinho da Silva Prado, irmão do conselheiro, a modernidade tinha por representação a República, o que evidencia a divisão no próprio seio familiar dos Silva Prado, que operavam seus negócios como clã no que viria a ser um projeto mais imediato de modernidade para o país, ainda que em perspectiva mais ampla este projeto signifique claramente uma modernização conservadora.

A família Silva Prado era detentora de inúmeras fazendas de café no interior paulista, acionista e proprietária de companhias de estrada de ferro, como a Paulista e a Sorocabana, banqueiros, comerciantes no setor de frigorífico, vidros, importação e

\footnotetext{
${ }^{3}$ Também foi fundada em 1827 a Faculdade de Direito de Olinda, transferida em 1852 para a cidade de Recife.
} 
exportação ${ }^{4}$. Após a morte do barão de Iguape em 1875, a liderança da família coube à sua filha Veridiana da Silva Prado, mãe de Antônio e Martinho.

Em 1877, a matriarca Silva Prado passou a receber em sua mansão os colegas e amigos dos filhos mais novos, Caio e Eduardo, estudantes da Faculdade de direito do Largo São Francisco, em uma espécie de ensaio de um salão cultural, onde Veridiana orientava as discussões sobre política, literatura e música. Segundo Wanderley Pinho, era um hábito aristocrático que vinha do Império a reunião de pessoas de alta condição social com aquela parte da intelectualidade. A exemplo dos salões de conhecimento de Paris e Londres que eram uma:

Forma privilegiada da sociabilidade da alta burguesia, a mundanidade consistia em reunir em casa um público seleto para concertos, espetáculos e bailes. (...) As festas íntimas tornam-se noitadas em sociedade e a sala da família converte-se em salão. Extrapolando o círculo fechado e restrito de amigos próximos, o novo espaço não servia ao lar, mas à sociedade. O privado da residência transformava-se em cenário público de representação que dava imenso prestígio aos seus anfitriões. (CAMARGOS, 1999, p.37)

Após uma temporada com a filha Ana Blandina, que residia em Paris, Veridiana traz consigo não apenas uma ideia mais sólida, mas também a vivência dos grandes salões culturais que ocorriam na Europa, algo que por certo não passaria desapercebido à uma mulher que gostava da vida social. Em 1883, ela começou a executar o seu plano de introdução do salão cultural aos moldes franceses em São Paulo. No mesmo ano, iniciase, na chácara em que já residia, a construção de palacete em estilo renascentista francês, rodeado por um refinado jardim de inspiração inglesa. A construção que mereceu anotação no diário da princesa Isabel foi um marco da modernidade, modificando e influenciando os parâmetros paulistanos de construção e habitação, introduzindo na cidade o conceito italiano de "vila residencial" que seria seguido por outras famílias, como a vila Penteado, vila Matarazzo e a residência de Freitas Valle, denominada Villa Kyrial.

O novo palacete de Veridiana da Silva Prado era elemento constitutivo da reorganização do capital simbólico de sua anfitriã, de seu salão que entrava em nova fase e, por consequência, de seu prestígio social, elementos que somados consolidam a já poderosa rede de capital social dos Silva Prado. A construção em estilo europeu da sede do salão apontava e marcava a inspiração dos Silva Prado em seu projeto de modernidade.

\footnotetext{
${ }^{4}$ Casa de Comércio Prado \& Chaves, uma das mais importantes casas comerciais de venda de café para o exterior no final do século XIX e início do XX. Em 1909, incorporou ao seu patrimônio 17 fazendas de café, fruto de penhoras não pagas.
} 
Começou a funcionar em 1885, no palacete vila Maria o salão cultural dirigido por Veridiana, este mais amplo e prestigiado que o anterior, o qual passou a circular políticos, banqueiros e diplomatas, como Antônio da Silva Prado, Martinho Prado Júnior, Elias Pacheco Chaves, Joaquim Nabuco, o barão do Rio Branco, Graça Aranha ${ }^{5}$, que participou da Semana de Arte Moderna de São Paulo em 1922; os escritores abolicionistas José do Patrocínio e Teodoro Sampaio; cientistas como Löfgren ${ }^{6}$, botânico sueco e um dos precursores do código florestal brasileiro ${ }^{7}$, e Orville Derby ${ }^{8}$, geólogo norte americano que faz as primeiras pesquisas acerca do solo paulista, trilhas indígenas e rotas bandeirantistas, tendo fundado o Serviço Geológico e Mineralógico do Brasil com o apoio financeiro de Veridiana da Silva Prado, incorporado em 1920 ao Ministério da Agricultura, Indústria e Comércio; os historiadores Capistrano de Abreu ${ }^{9}$, um dos principais contrapontos da história do Brasil escrita por Adolfo de Varnhagen e Afonso Taunay $^{10}$, diretor do Museu Paulista entre 1917 e 1945; os pintores Benedito Calixto ${ }^{11}$, Almeida Júnior e Pedro Alexandrino Borges ${ }^{12}$, que foi professor de Tarsila do Amaral (1917), Anita Malfatti (1919), artistas do movimento modernista, e Aldo Bonadei (1925), integrante do chamado Grupo Santa Helena.

A verdadeira fama da Vila Maria não residia apenas na originalidade de sua arquitetura e na beleza dos seus jardins (...). Era o palacete da intelectualidade paulista, o centro das discussões literárias e o lugar de peregrinação dos homens ilustres e jovens promissores, cujo talento começava a desabrochar. A heterogeneidade do grupo enriquecia a vivacidade dos debates. (D`ÁVILA, 2004, p.241)

A mesma heterogeneidade que, segundo D`Ávila, enriquecia a vivacidade dos debates não anulava as predisposições ideológicas e posicionamentos de seus anfitriões que não deixavam de selecionar os convidados considerados aptos a participar do salão; seja qual fosse o critério escolhido, havia uma seleção e, portanto, um direcionamento que partia da realidade, horizonte e convicções, mais alargadas ou conservadoras do anfitrião. Por propiciar o entrelaçamento entre as mais distintas vertentes, o salão torna-

\footnotetext{
${ }^{5}$ José Pereira de Graça Aranha (1868-1931) foi um dos fundadores da Academia Brasileira de Letras.

${ }^{6}$ Johan Albert Constantin Löfgren (1854-1918), botânico sueco.

${ }^{7}$ O Código Florestal brasileiro foi aprovado em 1934.

${ }^{8}$ Orville Adelbert Derby (1851-1915), geólogo estadunidense.

${ }^{9}$ José Capistrano Honório de Abreu (1853-1927).

${ }^{10}$ Afonso d'Escragnolle Taunay (1876-1958), membro da Academia Brasileira de Letras eleito em 1929.

${ }^{11}$ Benedito Calixto de Jesus (1853-1927), pintou sob encomenda de Afonso d'Escragnolle Taunay quadros para a composição de acervo do Museu Paulista.

12 Pedro Alexandrino Borges dos Santos Fernandes (1856-1942), pintor e professor no Liceu de Artes e Ofícios de São Paulo.
} 
se, em alguma medida, ferramenta estratégica que ultrapassa a maximização do prestígio social, visando também a promoção e o direcionamento de políticas, tanto em âmbito privado como público, sobretudo, quando os atores envolvidos transitam facilmente pelos postos de poder no governo, tanto no período imperial como no republicano.

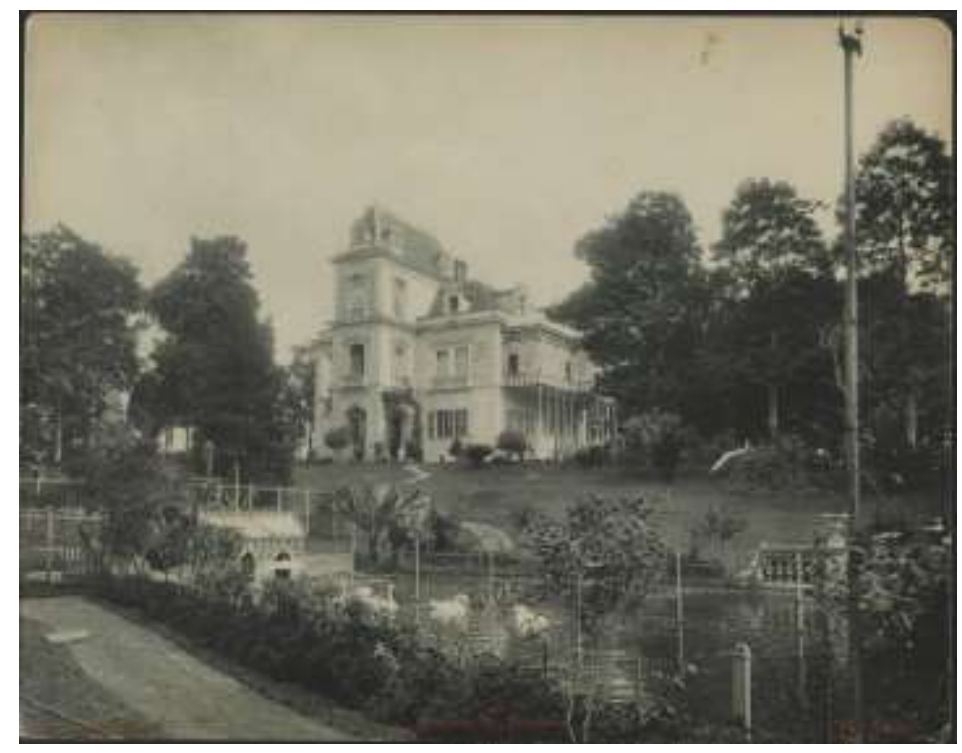

Chácara de Dna. Veridiana Valéria da Silva Prado em 1902. Autor: Guilherme Gaensly. ${ }^{13}$

Os salões eram espaços de ampliação da rede de relações, quando se considera a inserção de novos membros convidados, mas também de consolidação e de aumento do prestígio do capital social, que segundo Bourdieu pressupõe:

o conjunto dos recursos reais ou potenciais que estão ligados à posse de uma rede durável de relações mais ou menos institucionalizadas de interconhecimento e de inter-reconhecimento mútuos, ou, em outros termos, à vinculação a um grupo, como o conjunto de agentes que não somente são dotados de propriedades comuns, mas também que são unidos por ligações permanentes e úteis.

(BOURDIEU, 1998 p. 67).

A rede de relações sociais dos Silva Prado já possuía sólida consistência política e econômica no final do século XIX, mas é no salão da grande matriarca e mecenas da família que estas duas esferas se entrelaçaram com a ciência e as artes, campos que requeriam mecenas e seus financiamentos - que eram também articulados nos grandes salões - na esfera privada pelo próprio anfitrião ou por suas empresas, e na esfera política por financiamentos facilitados pelos ocupantes de cargos diretivos do Estado, presidentes, governadores, ministros de Estado que compunham a rede social do anfitrião.

13 Biblioteca Nacional. Disponível em: http://brasilianafotografica.bn.br/brasiliana/handle/bras/989 Acessado em 20.mar.2018. 
Independente da esfera de financiamento, público ou privado, os salões de Veridiana e Paulo da Silva Prado, Freitas Valle e Olívia Guedes Penteado, apontavam para a mesma direção, a modernidade, a partir da compreensão e perspectiva de seus anfitriões, membros da oligarquia cafeeira paulista.

O botânico Löfgren, em 1883, trabalhou na organização do museu particular de Joaquim Sertório que possuía relevante acervo arqueológico, etnográfico, mineralógico, zoológico e histórico. Dez anos depois, diante da junção do acervo Sertório e do Museu Provincial, tem-se a origem do acervo principal que constituiu o Museu Paulista, que na gestão do alemão Hermann von Ihering $^{14}$ teve como prioridade a história natural, a exemplo do Museu Nacional no Rio de Janeiro. Mas o direcionamento do museu muda em 1917 com a gestão de Afonso Taunay, que privilegia a narrativa histórica nacional pela perspectiva paulista com forte valorização e enobrecimento de eventos e personagens paulistas $^{15}$, elementos que marcaram o enobrecimento e a ascensão de matutos e sertanistas à condição de elite nacional, detentora de forte poder econômico e influência política. Os três agentes, Löfgren, von Ihering e Taunay, participavam do salão de Veridiana, assim como os pintores Pedro Alexandrino e Benedito Calixto, o que evidencia o entrelaçamento entre a política de Estado, ciência, arte, economia e os interesses da elite paulista, articulada nos salões, tendo o museu como elemento de prestígio local, produtor e reprodutor, portanto, legitimador cientifico e cultural do discurso conveniente para a elite dominante, a mesma que promovia os salões, cenário pouco distinto dos verificados nos museus inaugurados no nordeste brasileiro entre 1967 e 1968 pela Campanha Nacional dos Museus Regionais, dirigida por Yolanda Penteado, descendente deste sistema, e Assis Chateaubriand, político e grande empresário das comunicações.

As pesquisas de Löfgren também reverberou na Companhia Paulista de Estrada de Ferro, presidida por Antônio da Silva Prado, pioneira, em 1903, no estudo e implantação do sistema de reflorestamento, ação que visava a redução de gastos da Companhia. Em situação similar, os trabalhos do geógrafo e geólogo Orville Derby na Comissão Geográfica e Geológica de São Paulo ${ }^{16}$ e no Serviço Geológico e Mineralógico

\footnotetext{
${ }^{14}$ Foi diretor do Museu Paulista entre 1895-1916.

${ }^{15}$ Como o herói bandeirante; o patrono da independência do Brasil José Bonifácio; e o grito do Ipiranga, ato fundador do Brasil.

${ }^{16}$ A Comissão realizou os primeiros estudos amplos e sistemáticos de climatologia, botânica, hidrografia, zoologia, ocupação territorial, geografia, geologia e levantamentos cartográficos. A comissão foi extinta em 1931, quando integrava a Secretaria de Estado dos Negócios da Viação e Obras Públicas, sendo um dos embriões em 1938 do Instituto Geográfico e Geológico.
} 
do Brasil $^{17}$ contribuíram para a expansão da lavoura cafeeira e das estradas de ferro em São Paulo, além de fornecer relevante acervo especializado em múltiplas instituições, como o Museu Nacional no Rio de Janeiro e, em São Paulo, o Museu Paulista e o Museu de Zoologia da Universidade de São Paulo.

É intrínseca a relação existente entre o interesse privado e a ação pública, bem como o financiamento da ação pública orientada a partir de indicações e eventos sociais e culturais de âmbito privado, como os salões, e também o processo reverso, quando do interesse dos mecenas revela a importância de estudos sistematizados e locados em tais ambientes culturais, sobretudo em período inicial de efervescência da ciência no Brasil.

Segundo considerações de Persiani, a presença do salão de Dona Veridiana era uma referência para os intelectuais da época que participavam de modo ativo do discurso científico durante o processo de formação da identidade nacional (2012, p.92).

[Nos salões] Sucediam-se as tertúlias, as conferências, os concertos, as alegres reuniões de alada conversação, sob a fidalga e cavalheiresca regência do dono da casa, que recebia com liberdade e a graça de um grão-senhor florentino. (CAMARGOS, 1999, p.41)

O sucessor natural do salão de Veridiana da Silva Prado foi a Vila Kyrial, localizada na Vila Mariana, região próxima à prestigiada avenida Paulista. Segundo Márcia Camargos, Freitas Valle, seu anfitrião, comandava o salão de acordo com os moldes veridianos aprendidos durante intensa convivência, já que frequentava o salão da matriarca dos Prado desde os tempos de estudante da Faculdade de direito. Compareciam ao seu salão a nata da sociedade, poetas e artistas sem recursos, buscando apoio e proteção sob as asas da oligarquia paulista praticante de um tipo de mecenato que envolvia recursos particulares e públicos.

Construída em 1904 em estilo eclético, mas com fortes traços do classicismo francês, a Villa Kyrial passa por reforma em 1912, sendo construído ao lado da varanda central e do hall de entrada anexo usado como Galeria. Este anexo trazia em seu exterior quatro nichos que possuíam afrescos das musas da pintura, dança, música e escultura, em clara menção à mitologia grega e ao período clássico, assim como o próprio nome da residência, que tem por origem o termo grego kyrios, que significa Deus, Senhor. A mensagem de Freitas Valle era clara, a Villa Kyrial era o templo prestigioso das artes e ele, o seu Senhor. Não diferente do palacete de Veridiana da Silva Prado, a residência e espaço sede do salão de Freitas Valle também transmitia em sua arquitetura elementos

\footnotetext{
${ }^{17}$ A instituição foi incorporada ao Ministério da Agricultura, Indústria e Comércio na década de 1920.
} 
simbólicos que refletiam o gosto, predileção e direção do salão enquanto elemento potencializador do seu prestigiado poder simbólico e do seu capital social.

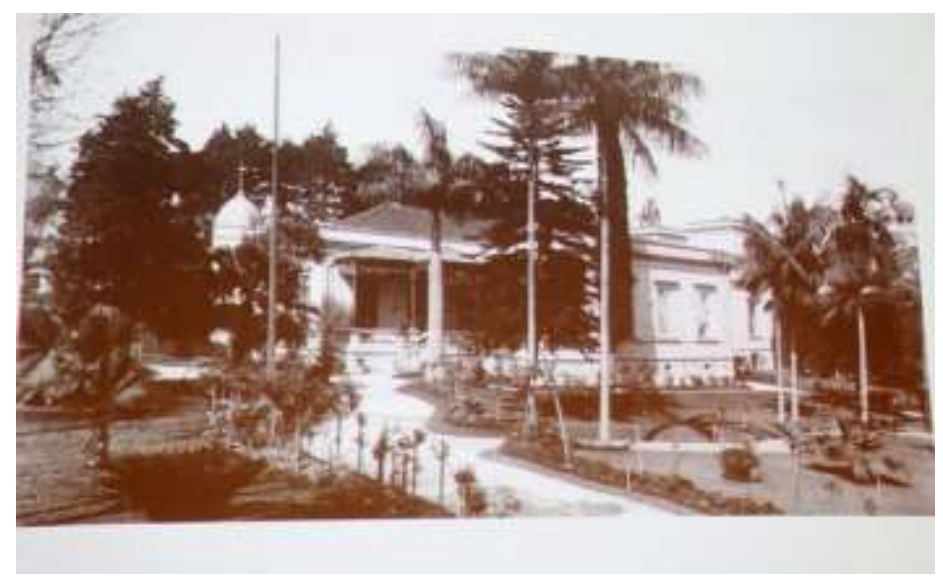

Villa Kyrial com os afrescos das musas das artes no anexo Autor: Otto Rudolf Quaas. ${ }^{18}$ (CAMARGOS, 2001, pp.49-50)

Em casamento cruzado, segundo termos de Claude Lévi-Strauss, os irmãos José e Luisa de Freitas Valle casam-se, respectivamente, com os irmãos Antonieta e Euclides Egydio de Sousa Aranha, membros de prestigiada família de cafeicultores do oeste paulista, netos da viscondessa de Campinas. Típico homem conservador da Belle Époque paulistana, Freitas Valle foi deputado e senador pelo Partido Republicano Paulista; amante da arte clássica e academicista, também foi professor do Liceu de Artes e Ofícios, importante instituição artística que esteve ligada à Pinacoteca do Estado em seu período inicial, o primeiro museu de arte de São Paulo.

No início do século XX, com algum contraste em relação aos cursos secundários, eram escassos os cursos superiores. Em São Paulo, haviam instituições como a Faculdade de Direito (1827), a Politécnica (1893) na área da engenharia, a Escola de Medicina (1914) e Escola de Farmácia e Odontologia. Vinculadas à esfera religiosa, passou a funcionar, em 1896, a Faculdade de Engenharia e Arquitetura Mackenzie (protestante) e, em 1908, a Faculdade de Filosofia São Bento (católica). E por fim, aberta em 1904, a Escola de Comércio Álvares Penteado, instituição fortemente ligada ao conde Antônio 
Álvares Penteado ${ }^{19}$, que tinha por genro dois filhos de Martinho da Silva Prado ${ }^{20}$ e Silvio, filho do conselheiro Antônio da Silva Prado. No campo das artes plásticas, as opções, segundo Gaziela Naclério Forte, restringiam-se à academicista Escola de Belas Artes no Rio de Janeiro e, em São Paulo, ao Liceu de Artes e Ofícios (1873), voltado a formação de $\operatorname{artesãos}^{21}$ e o Pensionato Artístico do Estado de São Paulo.

Em abril de 1912, foi sancionado pelo governo de São Paulo o projeto de lei ${ }^{22}$ apresentado pelo então deputado José de Freitas Valle, que criou e sistematizou as regras para obtenção de bolsas de estudo no exterior cedidas pelo Pensionato Artístico do Estado de São Paulo ${ }^{23}$, órgão também articulado com a Pinacoteca do Estado ${ }^{24}$. Dentre os critérios para a seleção, estava a aprovação do nome do candidato por uma Comissão, que teve como integrante nomes de peso como Olívia Guedes Penteado, Ramos de Azevedo e o próprio Freitas Valle, que, segundo a pesquisadora Márcia Camargos, exerceu influência determinante na comissão, mesmo quando não fazia oficialmente parte dela, evidenciando novamente o direcionamento e apropriação dos recursos públicos em benefício das tendências, interesses e opções feitas por esta mesma elite que financiava os eventos artísticos e culturais na esfera privada, dominando assim ambos os espaços, o público e o privado, em uma amálgama nada republicana ou democrática. Para Sérgio Miceli, o caso Freitas Valle:

(...) ilustra de modo exemplar um padrão de filantropia encontradiço no país, cujos magnatas praticantes, possuidores de grandes fortunas privadas, preferem exercer as atividades características do mecenato artístico mediante a mobilização de subvenções públicas, reservando o desembolso de recursos próprios para o enriquecimento de sua coleção particular. (MICELI, 2003, p.59)

A escassez de possibilidade de formação regular e prestigiosa no campo das artes plásticas em São Paulo, para além do Liceu de Artes e Ofícios, e a concessão de financiamento público para estudo no exterior por meio do Pensionato, destacam a centralidade de José Freitas Valle, figura preponderante em ambas as instituições públicas

\footnotetext{
${ }^{19}$ O filho primogênito do conde Antônio Álvares Penteado foi, em 1933, membro fundador da Fundação Escola de Sociologia e Política de São Paulo e, em 1947, da Fundação Armando Álvares Penteado (FAAP), instituição de ensino superior que nasce voltada à profissionalização no campo das artes.

${ }^{20}$ Caio da Silva Prado (pai de Caio Prado Jr.) e Martinho da Silva Prado Neto eram, respectivamente, casados com Antonieta e Stella, filhas do conde Antônio Álvares Penteado, que, por sua vez, era primo e cunhado de Olívia Guedes Penteado e tio paterno de Yolanda Penteado, presidente da Campanha Nacional dos Museus Regionais na década de 1960.

${ }^{21}$ CHIARELLI, Tadeu. Arte internacional brasileira. São Paulo: Lemos Editorial, 1999, p. 12.

${ }^{22}$ Decreto no $^{\circ} 2.234$ de 22 de abril de 1912.

${ }^{23}$ Victor Brecheret e Anita Malfatti foram alguns dos artistas contemplados com bolsas do Pensionato.

${ }^{24}$ Segundo o projeto aprovado de Freitas Valle, o escultor ou pintor bolsista deveria ao final do quinto ano de estudo enviar uma obra para a Pinacoteca do Estado.
} 
de prestígio destinadas à formação artística. Segundo Julio Moraes, a prova de que Valle gozava de ampla influência no panorama cultural e político é o fato de que as bolsas concedidas, tanto a Malfatti quanto a Brecheret que frequentavam o seu salão, violavam o regulamento do Pensionato, elaborado pelo próprio Freitas Valle. Ambos por excederem a idade máxima para concessão de bolsa e, no caso de Brecheret, ainda havia a polêmica questão da nacionalidade, já que a bolsa se destinava a artistas paulistas, e Brecheret havia nascido em Farnese na Itália.

Não raramente, a relação entre mecenas e artistas era mediada, em linhas gerais, pela troca de interesses, como coloca Graziela Forte.

Havia uma prática comum entre os artistas de darem conselhos, opiniões e orientações, possibilitando aos mecenas-colecionadores [caso de Freitas Valle] encontrarem pechinchas ou transações convidativas de aquisição ou encomenda. Em contrapartida, estes últimos valiam-se de seus contatos e indicações para a obtenção de informações, pedidos, nomeações e auxílio na indicação dos artistas para bolsas de estudos oferecidas pelo governo, numa troca de favores que se fazia por vezes acompanhar da doação voluntária de obras ou da venda de quadros e esculturas, preços depreciados, realizadas por alguns dos artistas agraciados com o prêmio de viagem, estudos e permanência no exterior oferecido pelo Pensionato Artístico Paulista-. (FORTE, 2010, p.274-275)

Circulavam pelo salão de Freitas Valle nomes como Heitor Villa-Lobos, Guilherme de Almeida, Menotti del Picchia, Mário e Oswald de Andrade, Anitta Malfatti e Victor Brecheret, que fora aluno do Liceu de Artes e Ofícios; artistas que na década de 1920 comporiam o movimento modernista e a Semana de Arte Moderna de 1922. Outros nomes como do filólogo e militante anarquista José Oiticica, os políticos Alfredo Pujol ${ }^{25}$, Goffredo da Silva Telles, Washington Luis ${ }^{26}$ e Júlio Prestes ${ }^{27}$, estes dois últimos, colegas de Freitas Valle no curso direito. Destes nomes merecem destaque o de Alfredo Pujol, um dos articuladores no governo para a abertura da Pinacoteca do Estado em 1900 também advogado da Companhia Guinle ${ }^{28}$, que detinha a concessão e administração do porto de Santos, e fora sócio do jornalista Assis Chateaubriand em seu primeiro jornal em

\footnotetext{
${ }^{25}$ Alfredo Gustavo Pujol (1865-1930). Advogado e jornalista, foi deputado estadual e federal entre $1901 \mathrm{e}$ 1912, ocupou a chefia da secretaria de governo do Estado de São Paulo na gestão de Bernardino de Campos e foi eleito em 1917 membro da Academia Brasileira de Letras.

${ }^{26}$ Washington Luis Pereira de Souza (1869-1957), cafeicultor e político, foi prefeito e governador de São Paulo, deputado estadual e federal, senador e presidente da república entre 1926-1930.

27 Júlio Prestes de Albuquerque (1882-1946), político, foi deputado federal, governador de São Paulo e eleito presidente da república, fora impedido pela Revolução de 1930 de assumir o cargo.

${ }^{28}$ Em 1909, a Companhia Guinle solicita por meio de petição apresentada pelo advogado Alfredo Pujol à prefeitura de São Paulo, administrada por Antônio da Silva Prado [filho de Veridiana], quebra do monopólio da Cia. Light and Power na operação dos serviços de bondes na cidade.
} 
São Paulo (1924). O Sr. Pujol era pai de Odila Pujol, cunhada de Yolanda Penteado, que na década de 1960 seria aliada de Assis Chateaubriand na Campanha Nacional dos Museus Regionais. Outro nome de relevo, Goffredo da Silva Telles ${ }^{29}$, nomeado prefeito de São Paulo em 1932, era genro de Olívia Guedes Penteado ${ }^{30}$, promotora de prestigiado salão de arte.

No mesmo período em que a lei que regulamentava a concessão de bolsas no Pensionato tramitava, Freitas Valle conheceu o pintor lituano Lasar Segall ${ }^{31}$, que estava no Brasil em visita à sua irmã, casada com Salomão Klabin, irmão do industrial Maurício Klabin. Com financiamento de Freitas Valle, o pintor faz suas primeiras exposições individuais no Brasil em 1913, nas cidades de São Paulo e Campinas, retornando, definitivamente, em 1923 ao país.

Em meados da década de 1910, embora o salão de Freitas Valle fosse um dos mais prestigiados, os salões de Paulo Prado e Olívia Guedes Penteado, já na década de 1920, passam a exercer papel determinante para o movimento modernista no campo das artes. Estes três salões possuíam em comum não apenas o café como subsidiário econômico, mas também fortes laços os uniam à política paulista. Se José Freitas Valle era senador da república e casado com a prestigiada família Souza Aranha, Paulo Prado era neto de Veridiana e filho do conselheiro Antônio da Silva Prado, que por sua vez era sogro de Guiomar [irmã de Yolanda Penteado] e Eglantina Penteado, filha do conde Alvarez Penteado, primo e cunhado de Olívia Guedes Penteado. Deste modo, por laços de parentesco e capital social, interliga-se os anfitriões dos grandes salões a alguns dos principais movimentos artísticos de São Paulo e do país no século XX e XXI, como a Semana de Arte Moderna (1922), a fundação do Museu de Arte de São Paulo (1947), Museu de Arte Moderna de São Paulo (1948), Bienal Internacional de Arte de São Paulo (1951), Museu de Arte Contemporânea de São Paulo (1963) e a Campanha Nacional dos Museus Regionais (1967), sem desconsiderar os laços familiares e societários que ligam Yolanda Penteado ${ }^{32}$ à família Moreira Salles, acionistas do Unibanco, mantenedor do

\footnotetext{
${ }^{29}$ Goffredo Teixeira da Silva Telles (1888-1980). Cafeicultor da região de Araras, advogado e poeta. Foi membro da Academia Paulista de Letras. Junto à sua esposa Carolina Penteado da Silva Teles, foi membro fundador, tendo assinado a ata e o registro em cartório de fundação do Museu de Arte Moderna de São Paulo (MAM-SP) em 1948. Foi ainda sogro da escritora Lygia Fagundes Teles (1923), membro desde 1985 da Academia Brasileira de Letras.

30 Tia de Yolanda Penteado (1903-1983).

${ }^{31}$ Lasar Segall nasce em 1891 na cidade de Vilna, atual Lituânia, região que entre 1795 e 1918 esteve anexada pelo império russo.

32 O primeiro esposo de Yolanda Penteado, Jayme da Silva Telles, além de primo de Goffredo da Silva Telles, genro de Olívia Penteado, tia de Yolanda, era cunhado de Otávio de Alves Lima, principal sócio da
} 
Instituto Moreira Sales; e o parentesco da esposa de Freitas Valle com os Egydio Sousa Aranha, principais acionistas do banco Itaú ${ }^{33}$, mantenedor do Instituto Itaú Cultural, que tem em comum com o Museu de Arte Moderna de São Paulo sua presidente, Maria de Lourdes Egydio Villela. Ambas instituições do mercado financeiro vinculadas aos descendentes dos cafeicultores paulistas, que estão fortemente presentes no cenário cultural e artístico nacional no século XXI.

Existe grande relação entre os anfitriões dos salões, o mecenato e a predileção pessoal por artistas e suas correntes estilísticas. Se o gosto pessoal de Freitas Valle estava voltado para o clássico, o de Olívia Guedes, que vivera na década de 1910 em Paris, estava amplamente aberto para a arte moderna de Léger, Matisse, Segall, Malfatti, Tarsila e Brecheret. Até o retorno definitivo de Olívia ao Brasil em 1923, esta recebia todas as terças-feiras políticos, diplomatas, intelectuais e artistas brasileiros em sua residência, ganhando a fama de verdadeiro embaixador do Brasil na França. O seu salão em São Paulo foi uma espécie de extensão daquele que ocorrera em Paris, adepto e aberto a arte moderna, possuía uma sala dedicada a esta vertente, decorada por Lasar Segall.

Mas, na segunda metade da década de 1910, no salão de José de Freitas Valle, já era possível observar a circulação de alguns artistas que integrariam o grupo modernista de 1922, embora a ideia da Semana de Arte Moderna tenha nascido no breve salão de Paulo Prado, sendo ele mecenas e integrante do grupo organizador da Semana que contaria com o nome de artistas e políticos que frequentavam o salão de Freitas Valle, somados a outros nomes.

Paulo Prado era um próspero empresário, industrial e cafeicultor, defendia, como o seu pai, a modernização do país e do mercado brasileiro que, na década de 1920, não precisava abolir a escravidão e incentivar a imigração, mas sim, diversificar a matriz econômica nacional ainda dependente da elite agrária, acomodada em sua condição e privilégios. Apesar da crítica de Paulo Prado à aristocracia paulista, o seu discurso modernizador estava calcado no mesmo sentido conciliatório defendido por Antônio da Silva Prado acerca da abolição nas décadas de 1870/1880. Ambos defendiam, em seus respectivos momentos, que a elite assumisse o seu papel e responsabilidade na modernização do país. Assim como o seu pai, Paulo Prado não defendia rupturas bruscas

família Moreira Salles na Casa Bancária aberta em 1924 na cidade de Poços de Caldas, no estado de Minas Gerais.

${ }^{33} \mathrm{Em}$ 2008, foi anunciada a fusão entre os bancos Itaú e Unibanco, criando assim o maior banco privado da América Latina. Segundo Poeta Souza e Murcia, estudos revelam que o anúncio de reorganização societária [fusão] impacta positivamente no valor do patrimônio das empresas. 
com a elite agrária, mas sim, a sua modernização, ainda que esta se insira no conceito de modernização Conservadora de Florestan Fernandes, onde a mudança das alegorias é realizada para conservar a estrutura. Para Paulo Prado:

Era preciso modernizar os meios de produção e de comercialização do café, não prescindindo de manter-se a classe oligárquica como hegemônica dentre as demais classes dominantes, porém, abrindo-se para os influxos modernizadores da indústria, do moderno e do urbano, atraindo a adesão das forças identificadas com esta perspectiva, como a própria burguesia industrial.

(PIVA, 2009 pp.145-146)

A historiadora da arte Aracy Amaral apresenta em sua pesquisa Artes Plásticas na Semana de 22, texto redigido ${ }^{34}$ por Mário de Andrade anos após a famosa semana, onde o autor aborda com agudeza a questão do tradicionalismo-internacionalismo, apresentando argumentos próximos aos defendidos por Paulo Prado, ainda que em clara política de modernização conservadora, projeto o qual Olívia Guedes Penteado se aproxima na década de 1920.

O modernismo, no Brasil, foi uma ruptura, foi um abandono de princípios e de técnicas consequientes, foi uma revolta contra o que era a inteligência nacional. (...) as modas que revestiram este espírito foram, de início, diretamente importadas da Europa. Quanto a dizer que éramos, os de São Paulo, uns internacionalistas, uns antitradicionalistas europeizados, creio a ser falta de sutileza crítica. É esquecer todo o movimento regionalista aberto justamente em São Paulo e imediatamente antes, pela "Revista do Brasil"; é esquecer todo o movimento editorial de Monteiro Lobato; é esquecer a arquitetura e até o urbanismo (Dubugras) neo-colonial, nascidos em São Paulo. Desta ética estávamos impregnados. Menotti del Picchia nos dera o 'Juca Mulato', estudávamos a arte tradicional brasileira e sobre ela escrevíamos; e canta regionalmente a cidade materna o primeiro livro do movimento. Mas o espírito modernista e as suas modas foram diretamente importados da Europa.

(AMARAL, 1998 pp.116-117)

A chamada modernização conservadora reside no espaço de trânsito entre o regional e o internacional, o brasileiro e o europeu; neste primeiro momento, logo substituído pelo modelo de inspiração norte-americano. Reside neste trânsito entre o regional e o internacional os projetos da Bienal Internacional de Artes (1950) e o da Campanha Nacional dos Museus Regionais (1960), em pleno contexto de Guerra Fria. É possível vislumbrar em ambos esta mesma articulação entre o regional, o nacional e o internacional, a parte e o todo, processo selecionado e dirigido pelos interesses do mesmo

\footnotetext{
34 "O Movimento Modernista". In: Mário de Andrade: Aspectos da literatura brasileira. São Paulo, Martins, 1974. pp.235-236
} 
grupo oligárquica paulista, o qual financia o movimento e se apropria das alusões ao moderno, urbano e industrial, elementos estes que interessavam a estes em uma modernização conservadora, que mantinha o seu status quo deste grupo enquanto prestigiosa classe dirigente.

A obra de Paulo Prado dialogava com Capistrano de Abreu e Manuel Bonfim, publicada em 1928, no seio dos debates modernistas, Retrato do Brasil: Ensaio sobre a tristeza brasileira, apresentando uma perspectiva pessimista e negativista, onde a necessidade de mudança e imposição da modernidade são imperativos para o progresso do país. No mesmo ano, Mário de Andrade publicou Macunaíma, um herói sem caráter que deixa a tribo para viver na cidade grande, retrato do processo de crescimento dos centros urbanos; ainda que Macunaíma não possuísse espírito empreendedor e sempre repetisse a frase "Ai! Que preguiça!"; sem acesso à saúde e com excesso de formiga, o qual, segundo o narrador onisciente, "se aborreceu com tudo e foi-se embora e banza solitário no campo vasto do céu".

É possível estabelecer intenso diálogo e comparações entre as duas obras que se inserem no movimento modernista, onde buscam, para além de retratar, indicar os problemas do atraso brasileiro em clara e explícita proposta de mudança, de rompimento com o passado conservador herdado, direção não muito diferente das apontadas nas décadas seguintes por estudos historiográficos e sociológicos realizados na Escola de Sociologia e Política e na Universidade de São Paulo pelos chamados intérpretes do Brasil, como Sérgio Buarque de Holanda, Florestan Fernandes e Caio Prado $\mathrm{Jr}^{35}$.

Mário de Andrade em discurso proferido em 1942 na Casa do Estudante do Rio de Janeiro enfatiza traços do movimento modernista, alguns dos quais coadunam com as necessidades vislumbradas pelas elites no contexto pós Segunda Guerra Mundial, executado com a abertura de museus em São Paulo ${ }^{36}$, alinhados com a ideia de civilidade europeia (MASP) e a modernidade urbana e industrial (MAM-SP); por fim, a divulgação deste projeto exitoso em outras regiões do país, disseminando o mesmo discurso de interesse capitalista de modernidade articulado com a valoração nacionalista em diálogo com o internacional capitalista na Campanha Nacional dos Museus Regionais (1960) em pleno contexto do pós Golpe Militar de 1964 e Regime Militar brasileiro.

(...) o movimento modernista era nitidamente aristocrático. Pelo seu carácter de jogo arriscado, pelo seu espírito aventureiro ao extremo,

\footnotetext{
${ }^{35}$ Caio da Silva Prado Júnior (1907-1990) era neto de Martinho da Silva Prado Júnior, filho de Veridiana e irmão do conselheiro Antônio da Silva Prado, pai de Paulo Prado.

${ }^{36}$ Detentor de significativo pólo industrial brasileiro.
} 
pelo seu internacionalismo modernista, pelo seu nacionalismo embrabecido, pela sua gratuidade antipopular, pelo seu dogmatismo prepotente, era uma aristocracia do espírito (...)A burguesia nunca soube perder, e isso é que a perde. Si Paulo Prado, com a sua autoridade intelectual e tradicional, tomou a peito a realização da Semana, abriu a lista das contribuições e arrastou atrás de si os seus pares aristocratas e mais alguns que a sua figura dominava (...)

(BOSI, 1973 pp.299-300)

Em 1924, a mesma Olívia Guedes Penteado, que percorria os ateliês e galerias francesas ao lado da amiga Tarsíla do Amaral, definitivamente retorna para São Paulo, onde passa a receber em seu palacete nos Campos Elíseos. Assim como Freitas Valle construira um anexo na Villa Kyrial, Dona Olívia encomenda a construção de um pavilhão no antigo estábulo de sua residência, destinado às obras modernistas ${ }^{37}$, que assim não entrariam em contraste com a decoração mais clássica de sua residência. A decoração do novo anexo modernista na residência de Olívia Guedes Penteado ficou a cargo do pintor e escultor Lasar Segall.

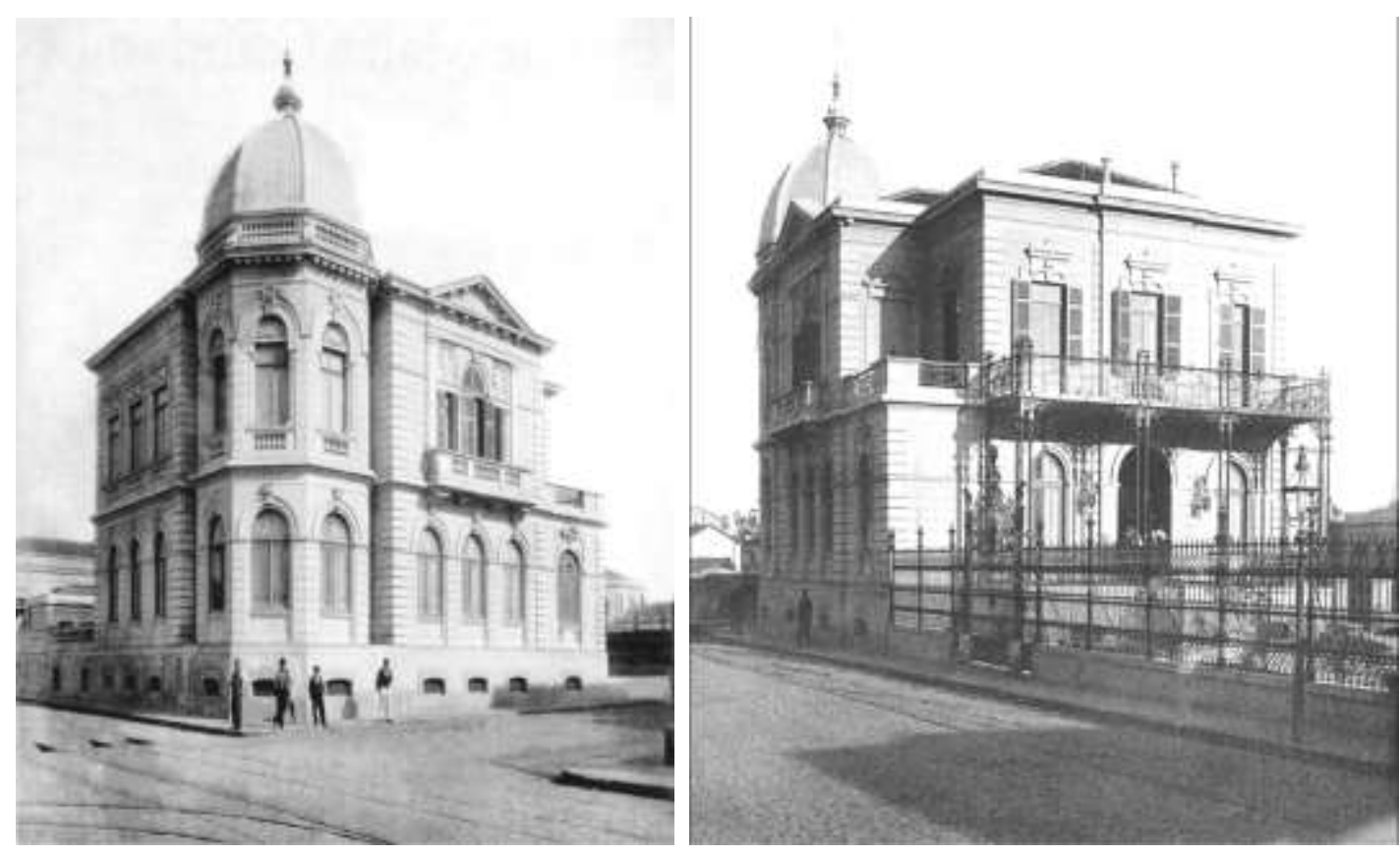

Residência de Inácio Penteado e Olívia Guedes Penteado em 1900, projeto do escritório de Ramos de Azevedo. Neste mesmo palacete, em 1924, Dna. Olívia passou a receber os artistas modernistas, que a chamavam de Nossa Senhora do Brasil. ${ }^{38}$

O mesmo palacete que recebeu os artistas modernistas, em requintado ambiente de salão de artes, também acolheu, em 1927, a fundação da Sociedade dos Amigos dos

\footnotetext{
${ }^{37} \mathrm{O}$ acervo Guedes Penteado incluia obras de artistas brasileiros como Tarsíla do Amaral, Brecheret, Portinari e Di Cavalcanti e obras adquiridas durante sua temporada no exterior, como Brancusi, Delaunay, Foujita, Cézanne, Degas, Marie Laurencin, Picasso e Léger,

${ }^{38}$ Autor: Otto Rudolf Quaas. Imagens pertencentes ao acervo do Instituto Moreira Salles (IMS).
} 
Monumentos Históricos do Brasil, que anteriormente a criação do $S P H A N^{39}$ em 1937, já indicava em seu estatuto, redigido pelo poeta francês Blaise Cendrars, a finalidade de:

$$
\begin{aligned}
& \text { proteção e a conservação dos monumentos históricos do Brasil. Igrejas, } \\
& \text { palácios, mansões, casas particulares dignas de interesse (móveis, } \\
& \text { objetos e obras de arte, pintura, estátuas, livros e arquivos, prataria (...). } \\
& \text { Constituir tantos Comitês de Iniciativa quantos são os Estados do } \\
& \text { Brasil. O Presidente de cada Comitê de Iniciativa faz parte do Comitê } \\
& \text { Diretor, na qualidade de Delegado de Estado. } \\
& \text { (FARIA; ARÊAS \& AGUIAR, } 1997 \text { p.323) }
\end{aligned}
$$

Entre os integrantes do Comitê Diretor figuravam nomes como o da própria Olívia Guedes Penteado, Paulo Prado e Oswald de Andrade, e entre os sócios Carlos de Campos, presidente do Estado na altura, Mário de Andrade, Tarsíla do Amaral, Carolina Guedes Penteado e Goffredo da Silva Telles. Por fim, em 1931, o palacete também recebe o príncipe de Gales e o duque de York em recepção organizada por Dona Olívia, atendendo a pedido de Getúlio Vargas, e assiste a ações promotoras da campanha eleitoral de Carlota Pereira de Queiroz, médica, amiga pessoal de Olívia Guedes, sendo a primeira mulher eleita deputada federal em 1934.

A década de 1920 foi palco da ebulição do desejo de transformação político e social, a exemplo da Semana de Arte Moderna de São Paulo (1922), movimento tenentista, Coluna Prestes (1925), fundação do Partido Comunista (1922), Partido Democrático Paulista (1925), dissidente do conservador $\mathrm{PRP}^{40}$ e da criação do Bloco Operário Camponês (1928), além da publicação de manifestos e artigos escritos por artistas que, segundo Dutra, revelam ímpetos de reforma e do rebuliço que agitava o país, movimentado pelos que clamavam por um Brasil novo e conciliador com a modernidade, cenário o qual se inseria a tradicional aristocracia paulista representada por Paulo Prado, Olívia Guedes Penteado e Oswaldo Aranha, que caminhavam no sentido da defesa da modernidade, sendo este último, sobrinho do senador Freitas Valle, deposto pela revolução de 1930, a mesma que elevou Aranha à condição de ministro de Estado do governo Getúlio Vargas.

A Revolução de 1930 impõem nova realidade aos mecenas dos salões, que gradualmente deixam de articular suas políticas e interesses no espaço privado dos salões e passam a exercer interferência e direcionamento ao financiar ações de artistas, que passam a se organizar em grupos e sociedades de interesse público, mantendo assim sua

\footnotetext{
${ }^{39}$ Serviço do Patrimônio Artístico Nacional - vinculado ao Ministério da Educação e Saúde, nasce no governo de Getúlio Vargas.

${ }^{40}$ Partido Republicano Paulista.
} 
influência. Mesmo diante a imposição desta nova realidade, os grandes agentes financiadores permanecem os mesmos, os acusados descendentes da tradicional aristocracia paulista.

O nosso sentido era especificamente destruidor. A aristocracia tradicional nos deu mão forte, pondo em evidência mais essa geminação de destino - também ela já então autofagicamente destruidora, por não ter mais uma significação legitimável. Quanto aos aristôs do dinheiro, esses nos odiavam no princípio e sempre nos olharam com desconfiança. Nenhum salão de ricaço tivemos, nenhum milionário estrangeiro nos acolheu. Os italianos, os alemães, os israelenses se faziam de mais guardadores do bom senso nacional que Prados e Penteados e Amarais. (BOSI, 1973 p.299)

Segundo Sérgio Miceli,

se na Primeira República o recrutamento dos intelectuais se realizava em função da rede de relações sociais que eles estavam em condições de mobilizar e as diversas tarefas de que se incumbiam estavam quase por completo a reboque das demandas privadas ou das instituições e organizações da classe dominante, a cooptação das novas categorias de intelectuais continua dependente do capital de relações sociais. (MICELI, 2003, p.59)

Esta revolução realinha o espaço artístico paulista diante do declínio dos salões que ocorriam em ambiente privado, dando força ao surgimento de clubes e associações de arte, os quais, em alguns casos, teriam por participante os mesmos artistas, intelectuais e anfitriões que frequentavam os salões, como a Sociedade Pró-Arte Moderna (1932), que tinha como integrantes Paulo Prado, Olívia Guedes Penteado, Mozart Camargo Guarnieri, Mário de Andrade, Tarsila do Amaral, Sérgio Milliet, Menotti del Picchia, Lasar Segall e o arquiteto Gregori Warchavchik, entre outros. Quase sempre estes grupos recebiam financiamento de figuras da aristocracia paulista, havendo pouca aderência destes em relação à ascendente burguesia industrial que possuía forte presença de imigrantes como os Matarazzo, Klabin, Siciliano, Jafet, entre outras famílias, como acusa Mário de Andrade. A iniciativa social resgatava experiências similares da década de 1910, como a Sociedade Cultura Artística, fundada por jornalistas ligados ao jornal $O$ Estado de São Paulo aliados aos mecenas Freitas Valle.

No mesmo ano em que surge o SPAM (Sociedade Pró-Arte Moderna), Di Cavalcante, figura reconhecida e valorizada no cenário internacional, que desempenhou expressivo papel na Semana de Arte Moderna e no movimento modernista, ao lado do empresário Carlos Prado ${ }^{41}$ e Flávio de Carvalho fundam o Clube de Artistas Modernos

\footnotetext{
${ }^{41}$ Ambos eram filiados ao Partido Comunista.
} 
(CAM), com a finalidade de promover reuniões, encontros, sessões de pintura, biblioteca especializada em arte, organização de uma revista, sendo ainda o espaço dotado de bar e restaurante, em ambiente aprazível para a realização de exposições e conferências. O dirigente financeiro do clube era Carlos Prado, irmão de Caio Prado Júnior, ambos sobrinhos do prefeito Fábio da Silva Prado (1934-1938) e filhos de Caio da Silva Prado ${ }^{42}$ e Antonieta Álvares Penteado, o que os tornava netos do conde Antônio Álvares Penteado e bisnetos de Veridiana da Silva Prado.

Embora o $S P A M$ e o $C A M$ fossem instituições semelhantes em seu objetivo e vinculação à elite promotora da modernização conservadora, o Clube dos Artistas distanciava-se da Sociedade Pró-Arte Moderna, por defender uma política mais radical, voltada ao comunismo. Di Cavalcante e o irmão de Carlos Prado, Caio Prado Júnior, foram filiados ao Partido Comunista do Brasil, sendo este último eleito por esta legenda e posteriormente cassado.

Como as atividades destas associações e sociedades não ocorriam em espaço residencial, estas passaram a gozar de maior liberdade à militância política aberta com tendências ao comunismo e o anarquismo, o que, na década de 1930, levour tais movimentos à marginalização em relação ao financiamento de mecenas e queda do prestígio social que gozavam em relação ao período dos salões, distanciando assim estes movimentos mais radicais dos braços do mecenato da aristocracia paulista, entre eles o Clube dos Artistas Modernos, que não contou com o apoio de grandes figuras como Freitas Valle, Paulo Prado, embora Carlos Prado - um dos dirigentes do CAM - fosse seu sobrinho, e Olívia Guedes.

Segundo considerações de Forte, o grupo tinha por objetivo a aquisição da sede social da agremiação; a expansão e aquisição de novo público para a arte moderna; buscar adequações culturais pertinentes ao início da década; e:

Um quarto e último objetivo tornou-se evidente somente no segundo semestre de 1933: unir arte e política para promover a divulgação da ideologia de esquerda. O grupo era inovador e radical mesmo tendo à frente jovens bem nascidos, pertencentes à elite. Eles viviam a fase inicial do processo de consciência de classe e mobilizavam-se na busca por mudanças sociais. (FORTE, 2010, p.284)

O Clube, que já nascera com sua sede própria, possuiu durante toda a sua existência situação financeira delicada, sendo sua renda principal as escassas doações de

\footnotetext{
${ }^{42}$ O casal Penteado Silva Prado teve três filhos: Ana Yolanda, Eduardo, Caio e Carlos, todos nascidos entre 1903 e 1908, portanto idades próximas à prima Yolanda Penteado (1903), que em sua autobiografia chega a descrever contato e alguma proximidade com estes primos.
} 
figuras como Carlos Prado e Flávio de Carvalho, a contribuição dos sócios e a realização de eventos. Mesmo com limitações orçamentárias e sua tendência esquerdista, o grupo buscou aproximação de outras agremiações, como o próprio SPAM, promovendo jantares e exposições com os principais artistas daquela agremiação, como Mário e Oswald de Andrade, Tarsíla do Amaral, Gregori e Mina Warchavchik, Kitty Boedenheim, a bailarina alemã recém chegada à São Paulo, e a promoção da Escola de Pintura Lasar Segall, que funcionava em seu ateliê na Vila Mariana, em região próxima à Villa Kyrial de Freitas Valle, hoje transformado em Museu Lasar Segall.

Mas o Clube paulista à despeito da competição no campo cultural existente entre a capital da república e São Paulo não se limitou a estabelecer contato com as agremiações locais, constituído por intermédio de Flávio de Carvalho, frutífero contato com a PróArte do Rio de Janeiro, dirigida pelo alemão dono de galeria de arte, Theodor Heuberger e pelo pintor Alberto da Veiga Guignad. Um dos primeiros frutos desta parceria foi o envio à São Paulo da mostra artística da alemã Kaethe Kollwitz, que, segundo Forte, a inscrevia no grupo dos chamados artistas socialistas, tendo como tema central os operários e a miséria, sendo que, uma de suas obras fora intitulada "Nós protegemos a União Soviética". Outro resultado da parceria foi o lançamento da revista Base, dirigida por Alexandre Altberg, arquiteto alemão com influências da Escola de Bauhaus, o qual mobilizou e publicou artigos de autores filiados ao Partido Comunista brasileiro, como Jorge Amado, Caio Prado Júnior e Oswald de Andrade, este também simpatizante e militante do anarquismo na década de 1930.

Um dos artistas que frequentou a agremiação, Paulo Mendes de Almeida, recorda como eram os encontros na sede do Clube de Artistas Modernos:

Em pouco tempo, o CAM tornou-se um ponto obrigatório de encontro para quantos, na cidade, achavam-se de qualquer forma ligados às manifestações artísticas e intelectuais. Mesmo da Capital e de outros centros do País, surgiram pessoas diretamente endereçadas àquele prédio da Rua Pedro Lessa, àquele ambiente agradável, onde a conversa e as discussões ferviam, à medida que os copos se esvaziavam; em torno às mesas que Sava e Pacha iam servindo. Muitas vezes, improvisaramse festas, danças que entravam ruidosas pela madrugada a dentro. Enfim, uma invulgar instituição.

(ALMEIDA, 1961, p.33)

A década de 1930 assiste o eclodir de agremiações semelhantes à Sociedade PróArte Moderna e ao Clube de Artistas Modernos, como o Salão de Maio, o qual participaram Tarsila do Amaral, Di Cavalcanti, Brecheret, Lasar Segall, Elias Chaves Neto; a Família Artística Paulista e o Grupo Santa Helena, que reunia artistas de ofício, 
decoradores, pintores de parede, desenhistas, figurinistas como Alfredo Volpi, Aldo Bonadei, Manuel Martins, entre outros. Além de multiplicar o número de associações e grupos de interesse público com finalidade artística, a cidade de São Paulo também foi palco, após a revolta paulista de 1932, da criação da Escola de Sociologia e Política de São Paulo (1933), que clamava em seu manifesto de fundação o avanço da modernidade e dos estudos científicos no país rompendo com a velha ordem, manifesto este assinado pelo conde Armando Álvares Penteado, Roberto Simonsen, então vice-presidente da Federação das Industrias do Estado de São Paulo, e pelo modernista Mário de Andrade.

A fundação da Escola de Sociologia é elemento importante no conjunto de iniciativas do período no sentido da modernização do país e da autonomia paulista do gerenciamento do governo federal, capitulado na altura por Getúlio Vargas, que possuía como instrumento Ministério da Educação e Saúde (1930), o Departamento de Imprensa e Propaganda (1939) para aliciar artistas ao seu projeto e o Departamento de Ordem Política e Social (1924) para reprimir os contestadores e opositores políticos. Para a historiadora Maria Helena Capelato, estas ações e instituições eram:

Fruto da ampliação da capacidade de intervenção do Estado, no âmbito dos meios de comunicação e da cultura, (...) [o Departamento de Imprensa e Propaganda], tinha como função elucidar a opinião pública sobre as diretrizes doutrinárias do regime, atuar em defesa da cultura, da unidade espiritual e da civilização brasileira.

(CAPELATO, 1997, pp.37-38)

Neste mesmo sentido, Graziela Forte enfatiza os novos campos de trabalho criado aos artistas pelo regime de Vargas, que atraia os artistas para o abrigo da tutela do Estado:

O DIP produziu livros, revistas, folhetos, cartazes, programas de rádio, fotografias, cinejornais, documentários cinematográficos e filmes de ficção para divulgar o discurso destinado a construir a imagem de instituições, do chefe de governo e do regime, identificando-os com o próprio país e seu povo. Tal projeto do Estado promoveu a profissionalização do artista e possibilitou o aumento do mercado de trabalho para os intelectuais, dentro do aparelho burocrático, durante a gestão de Gustavo Capanema no Ministério da Educação, o qual se transformou em lugar de mecenato, encontro e produção cultural. (FORTE, 2010 p.294-295)

A Escola de Sociologia, que no momento de criação esteve fora da tutela do governo federal chefiado por Vargas, em seus estudos iniciais indica a necessidade de conhecer o Brasil e formar uma elite intelectual capaz de conduzir o país à modernidade, lançando assim, a base ideológica necessária para a fundação da Universidade de São Paulo na gestão de Armando de Salles Oliveira no governo paulista, cunhado e sócio de Julio de Mesquita Filho no jornal O Estado de São Paulo. Na mesma década, em 1935, 
durante a gestão de Fábio da Silva Prado $^{43}$ na prefeitura de São Paulo, é criado o Departamento de Cultura chefiado por Mário de Andrade, que promove inúmeras ações inovadoras ao lado de nomes como Camargo Guarnieri, na orquestra filarmônica do município, e Sérgio Milliet, na divisão de documentação histórica e social e, posteriormente, na divisão de bibliotecas, onde cria, em 1944, a seção de arte em tentativa de suprir a necessidade de museus de arte na cidade para além da Pinacoteca do Estado, alinhada, até então, à arte clássica e academicista.

No final da década de 1930, Sérgio Milliet e o sociólogo norte-americano Donald Pierson compuseram o corpo docente da Escola de Sociologia e Política que, em 1940, incorporou o curso de biblioteconomia e documentação, que fora mantido até 1936 pela prefeitura de São Paulo ${ }^{44}$. Neste mesmo período, a Escola atrai financiamento do governo norte-americano por meio da Smithsonian Institution e alguma influência da University of Chicago em parceria com a Rockefeller Foundation ${ }^{45}$, que financiam trabalhos e pesquisas sociológicas e antropológicas acerca da realidade brasileira em áreas como trabalho, movimento operário, habitação, densidade populacional, transportes, custo de vida, entre outros estudos de pesquisa aplicada. Segundo Sérgio Milliet, a Escola inicia um processo de estudo, pesquisa e interpretação cientifica, portanto, moderna da realidade brasileira, enquanto o ensino superior da época era:

exclusivamente formal e produzia anualmente centenas de bacharéis inúteis e nenhum elemento de verdadeira cultura. A importância da fundação da Escola foi a renovação do ambiente intelectual, nosso ensino superior desumanizava o individuo, afastava da vida e enchialhe a cabeça de retórica barata. (O Estado de São Paulo, 20136)

É possível verificar a aproximação norte-americana de instituições culturais brasileiras na década de 1940, contexto da Segunda Guerra Mundial e, com o fim desta,

\footnotetext{
${ }^{43}$ Fábio da Silva Prado (1887-1963) era sobrinho do conselheiro Antônio Prado e neto de Veridiana da Silva Prado. Em 1914, casa-se com Renata Crespi, filha do industrial-imigrante Rodolfo Crespi, agraciado, em 1928, pelo governo italiano com o título nobiliárquico de conde. Este casamento foi um dos primeiros símbolos da união entre a velha aristocracia do café e a elite industrial emergente em São Paulo, situação semelhante ao casamento de Yolanda Penteado e Francisco Matarazzo Sobrinho nos anos 40. Em 1972, a antiga residência do casal passa a abrigar o Museu da Casa Brasileira e a coleção artística doada em 1963 pela viúva Renata Crespi.

${ }^{44}$ Durante gestão de Fábio da Silva Prado.

${ }^{45}$ Embora a origem e aproximação de setores conservadores da sociedade, a Escola de Sociologia e Política é o celeiro intelectual de pensamentos e ações alinhados à esquerda, a titulo de exemplo, nomes como Darcy Ribeiro e Florestan Fernandes passaram pela instituição, deixando significativas marcas, bem como os museólogos Waldisa Rússo Camargo Guarnieri e Maurício Segall.

${ }^{46}$ Disponível em: http://acervo.estadao.com.br/noticias/acervo, primeiro-curso-de-sociologia-do-paiscompleta-80-anos,9066,0.htm - acessado em 20.mar.2018.
} 
o início da Guerra Fria, momento em que o capitalismo assistiu ao crescimento da zona de influência da URSS, sobretudo na Europa.

Por sua vez, na esfera nacional, desde a década de 1930, o Estado buscou cercear e controlar as atividades culturais, segundo Capelato, em alguns momentos atendendo reivindicações de diversos setores que solicitavam a intervenção do Estado para fazer frente à concorrência estrangeira, que chegava ao país sobretudo em consequência da industrialização, fluxo imigratório e do avanço da cultura de massa. Já na esfera regional paulista, a antiga aristocracia cafeeira modernista buscou reorganizar as atividades culturais a partir das agremiações artísticas, entre elas a SPAM e, no campo da pesquisa e ensino superior não estatal, a Escola de Sociologia; na esfera pública, dando segmento às velhas práticas da República Velha com roupagem moderna, ocorreu a criação da Universidade de São Paulo na gestão do paulista Armando Salles de Oliveira e o Departamento de Cultura e suas pastas chefiadas por Mário de Andrade e Sérgio Milliet, criados na gestão do prefeito Fábio da Silva Prado.

É em consequência destas ações de âmbito nacional e regional, que no contexto de pós-guerra e de plena Guerra Fria que nasce o Museu de Arte de São Paulo (1947), articulado pelo político e empresário das comunicações Assis Chateaubriand, voltado à arte clássica europeia em projeto distinto ao que tencionava o industrial Nelson Rockefeller ${ }^{47}$, ainda que nas ações do museu houvesse a defesa de atividades modernas no campo do ensino, pesquisa e exposições. Mas é sob a direção do industrial ítalobrasileiro Francisco Matarazzo Sobrinho, casado com Yolanda Penteado, que Rockefeller encontrou a sua parceria em São Paulo por meio da fundação do Museu de Arte Moderna de São Paulo (1948), que teve por modelo inspirador o Museu de Arte Moderna de Nova Iorque, tendo na presidência, além de um dos seus fundadores, a presença da família Rockefeller, que forneceu assessoria, consultoria e doação de obras para a constituição do acervo do museu moderno em São Paulo, o qual teve como integrantes da diretoria, além de Matarazzo como mecenas, o intelectual Antonio Candido e o modernista e critico de arte Sérgio Milliet.

É na década de 1940 que o protagonismo da elite emergente industrial começa a vigorar mais fortemente no campo das artes em São Paulo, com grande destaque para as

\footnotetext{
${ }^{47}$ O grande dirigente e articulador no período foi Nelson Rockefeller (1908-1979). Mecenas e político norte-americano, foi presidente do Museu de Arte Moderna de Nova Iorque na década de 1940.
} 
ações de Chateaubriand na abertura do Museu de Arte de São Paulo ${ }^{48}$ (MASP) e de Matarazzo e Penteado na inauguração do Museu de Arte Moderna de São Paulo (MAMSP), sobretudo na composição da Bienal Internacional de Artes, o grande projeto de Matarazzo. O museu que teve sua primeira exposição na metalúrgica Matarazzo e, posteriormente, no prédio dos Diários Associados de Chateaubriand no centro de São Paulo pretendia valorizar o discurso do projeto moderno, urbano e industrial em contexto da Guerra Fria, ligando o Brasil aos grandes centros produtores de arte [capitalistas] e inserindo São Paulo neste grande circuito.

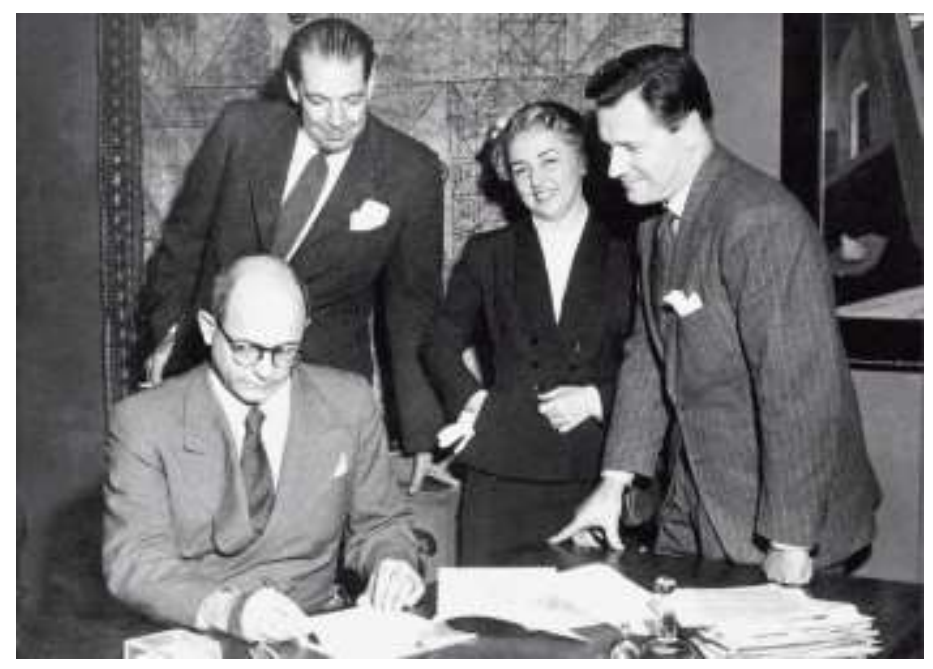

Assinatura de parceria em 1951 entre MAM-SP e MoMa-NY. Na imagem sentado Ciccillo Matarazzo, Yolanda Penteado e Nelson Rockefeller (Acervo: Fundação Bienal)

Em comum, o projeto de Chateaubriand ${ }^{49}$ e Matarazzo buscavam a projeção social por meio do mecenato; enquanto o primeiro estava ligado à velha aristocracia mais conservadora, com discurso civilizador da arte clássica e acadêmica, ao estilo Freitas Valle; o segundo vinculava-se ao projeto moderno, que, segundo Sevcenko, possui o sentido de abandono dos velhos paradigmas e a inserção do Brasil em nova etapa, marcada pela tecnologia e ciência, o novo urbano e industrial; era este o discurso que

\footnotetext{
${ }^{48} \mathrm{Na}$ inauguração do MASP em 1947, diante da presença do presidente da república Eurico Gaspar Dutra, Nelson Rockefeller em seu discurso fala sobre a filantropia de Chateaubriand, além de incluir no discurso palavras chaves do período e do interesse do sistema capitalista como democracia, paz e países intimamente ligados à aproximação que visava o distanciamento da ameaça representada pela URSS.

${ }^{49}$ Segundo Lourenço, já em 1926, o fundador do MASP, Assis Chateaubriand começa a pensar no museu com ajuda de Frederico Barata e do pintor Eliseu Visconti (1999, p.97). Esta afirmação torna Assis Chateaubriand o correspondente brasileiro em menor escala do movimento que ocorreu nos EUA na década de 1920 e 1930, onde milionários como Guggenheim, Whitney, Rockefeller e Ford tornam-se os principais responsáveis pelo fortalecimento da cultura e da arte no país, com a construção de museus, a aquisição de pinacotecas e obras de arte (MANTOAN, 2015, p.21).
} 
interessava a Francisco Matarazzo Sobrinho (Ciccillo), para além do prestígio social, discurso esse que desde Veridiana da Silva Prado, com algumas atualizações, era defendido ciclicamente por certos segmentos da elite cafeeira paulista, da qual Yolanda Penteado, esposa de Ciccillo, fazia parte por meio de seu tradicional capital social, outro mecanismo de modernização conservadora, partindo do principio da vigência e do interesse público nos espaços museais destinados ao público em geral.

O Museu de Arte Moderna de São Paulo (MAM-SP) recebe apoio de modernistas como Tarsila do Amaral e Anitta Malfatti na sua fundação e (re)inicia um processo de valoração de artistas modernistas como Di Cavalcanti, Alfredo Volpi, entre outros, cooptando artistas de tendência esquerdista ao discurso artístico defendido pelo museu, gerido pelos interesses do mecenas industriais em situação similar e adaptada dos grandes salões de conhecimento e arte de Veridiana, Freitas Valle, Paulo Prado e Olívia Guedes Penteado, esvaziando assim, as agremiações artísticas pouco prestigiosas e com tendências pouco interessantes à elite financeira, nacional e internacional, atenta às políticas empreendidas nos países da América Latina em contexto de Guerra Fria.

O surgimento do Estado Getulista fragiliza e reorganiza essas iniciativas isoladas, mas agora, partindo de uma ótica do Estado. Ciccillo, Yolanda e Chatô alinham-se a este projeto do Estado em prol do capital e do uso do museu como instituição de prestígío e civilidade, e da arte moderna e contemporânea como elementos discursivos favoráveis à urbanização, desenvolvimento industrial e, por consequência, ao avanço do capitalismo em oposição ao anarquismo e comunismo, que não interessavam à elite paulista, defensora da modernização conservadora, e nem ao Estado chefiado por Vargas, Dutra, Kubitschek ou aos militares.

A primeira Bienal Internacional de Arte de São Paulo (1951), assim como as demais que ocorreram na década de 1950, tiveram o MAM-SP como grande subsidiário, aliado à representação internacional de Yolanda Penteado, sobretudo na França e Itália, reduto do seu antigo e novo círculo social, contando com apoio institucional do Itamaraty e de Getulio Vargas, que não se opunham ao projeto prestigioso e elitista de interesse das camadas dominantes dirigida pelo mesmo grupo desde o final do século XIX.

Diante de conflitos internos, muitos em decorrência das bienais, grandes exposições que consumiam os recursos do museu de arte moderna, seu organizador, que ficava refém das bienais, é dissolvido e sua coleção principal é doada por Matarazzo e Penteado, constituindo, em 1963, o Museu de Arte Contemporânea vinculado à Universidade de São Paulo. 
No final da década de 1950, o MASP havia funcionado nos escritórios dos Diários Associados e nas salas da Fundação Armando Álvares Penteado (FAAP) ${ }^{50}$, ganhando sua sede definitiva na Avenida Paulista apenas em 1968, pouco depois da morte do empresário e diplomata Assis Chateaubriand. Yolanda era membro da diretoria e organizadora do evento de inauguração que contou com a presençaa da rainha da Inglaterra Elisabeth II e do duque Filipe de Edimburgo ${ }^{51}$.

Na década de 1960, com o fim do primeiro MAM-SP, Yolanda passa a integrar a equipe dirigente do MASP e logo é convidada por Assis Chateaubriand para presidir a Campanha Nacional dos Museus Regionais, que tinha por intenção abrir unidades de museus de arte no país. A campanha consistia na formação de acervo em processo semelhante ao utilizado no $M A S P$, doação ou aquisição, garantindo ampla visibilidade e divulgação aos mecenas nos veículos de comunicação de Chateaubriand; escolha da cidade sede do museu; organização da equipe dirigente do museu; e doação do acervo constituído. Neste processo, cabia à Yolanda Penteado desenvolver o papel de relações públicas, Chateaubriand endossar financeiramente os eventos, garantir a publicidade nos Diários Associados, e a Pietro Maria Bardi, selecionar e compor o acervo a ser doado.

O plano ambicioso de Penteado, Chateaubriand e Bardi era criar mecanismos de fomento da circularidade da arte pelo território nacional, tendo o MASP como ponto de partida e interlocução entre o nacional e o internacional, propiciando assim, o fomento da arte local e, em alguma medida, a influência de técnicas e estilísticas valorizadas no cenário internacional. A circularidade do projeto coadunava com a necessidade identificada pelo governo militar, após o golpe de 1964, de promover a integração do Brasil e o afastamento da ameaça comunista estando presente no discurso moderno, além da promoção do desenvolvimento urbano e industrial.

A arte moderna é a corrente mais valorizada pela Campanha Nacional, havendo grande envolvimento de dois artistas supervalorizados nas bienais de arte de São Paulo, Di Cavalcanti e Alfredo Volpi, que ampliavam o prestígio do acervo doado aos museus que foram abertos no sul, sudeste e nordeste do país, com projetos não concretizados na região norte.

\footnotetext{
${ }^{50}$ Instituição de ensino superior e pesquisa fundada em 1947 a partir dos bens deixados por Armando Álvares Penteado, primo-irmão de Yolanda Penteado, sobrinho de Olívia Guedes Penteado, irmão de Antonieta Penteado, casada com Caio da Silva Prado, pais de Caio Prado Jr. e Carlos Prado; irmão de Eglantina Penteado casada com Antônio da Silva Prado Júnior, filho do conselheiro Antônio da Silva Prado e irmão de Paulo Prado; e irmão de Stella Penteado, casada com Martinho da Silva Prado Neto, irmão de Fábio da Silva Prado, que fora prefeito de São Paulo no final da década de 1930.

${ }^{51}$ Chateaubriand foi embaixador do Brasil na Inglaterra.
} 
Uma das grandes críticas presentes nos jornais, sobretudo paulistas, que contrastam com a pompa e o prestígio apresentado pelos Diários Associados, é a criação de verdadeiros museus fantasmas diante da quase inexistência de público. Mas era a criação destas instituições que movimentava a articulação das elites locais entorno dos museus, visando atingir a distinção e o prestígio social, e inserir-se em projeto de expressão nacional, avalizado pelo prestígio paulista de Yolanda Penteado e pelo sucesso do MASP nas pessoas de Assis Chateaubriand e Pietro Maria Bardi.

No nordeste brasileiro são fundados o Museu de Arte Contemporânea de Pernambuco $^{52}$ (1966) em Olinda; o Museu de Arte Contemporânea Assis Chateaubriand (1967) em Campina Grande; e o Museu de Arte Contemporânea (1967) em Feira de Santana, todos em funcionamento, ainda que o museu de Olinda esteja temporariamente fechado ao público para reforma.

O projeto de circularidade das exposições e dos artistas nunca chegou a ser concretizado, em alguma medida, o falecimento de Chateaubriand, em abril de 1968, impôs dificuldades à manutenção do projeto, que não foi capitaneado pelo governo militar, por outros mecenas ou agentes internacionais durante o regime militar. Mesmo após a redemocratização no país, havendo iniciativas isoladas e total ausência de comunicação entre as instituições deste projeto de continuidade da chamada modernização conservadora, que atingiu outros pontos do território nacional, partindo da perspectiva e do prestígio de instituições e artistas construídos majoritariamente em São Paulo.

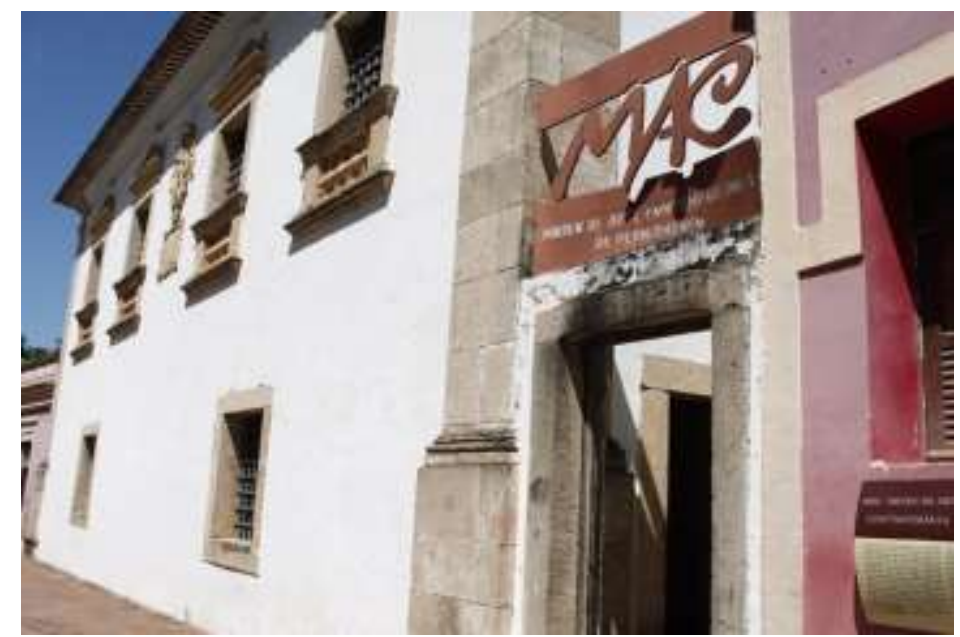

Museu Regional de Olinda - 2017 (Fechado ao público)

(Acervo do Autor)

\footnotetext{
${ }^{52}$ Aqui os museus encontram-se com seus nomes atuais para facilitar a compreensão e sua divulgação, e não os nomes conferidos no período de fundação.
} 

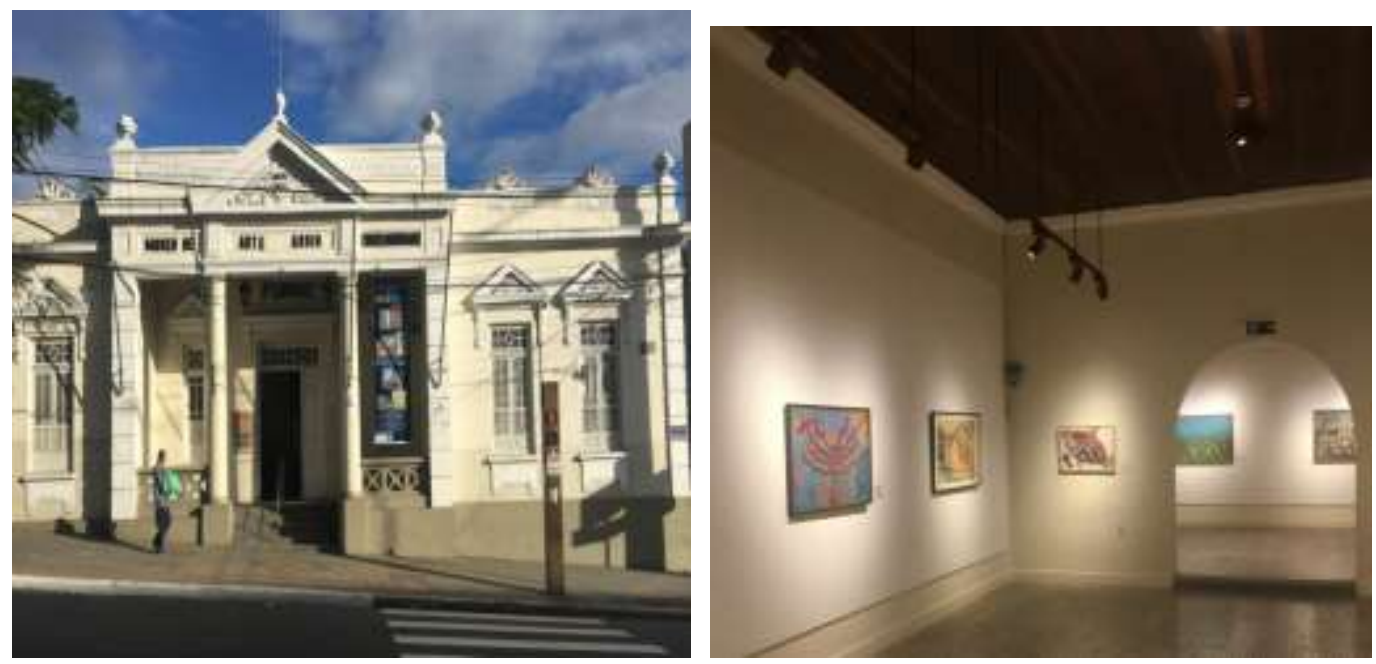

Museu Regional de Campina Grande - 2017

(Acervo do Autor)

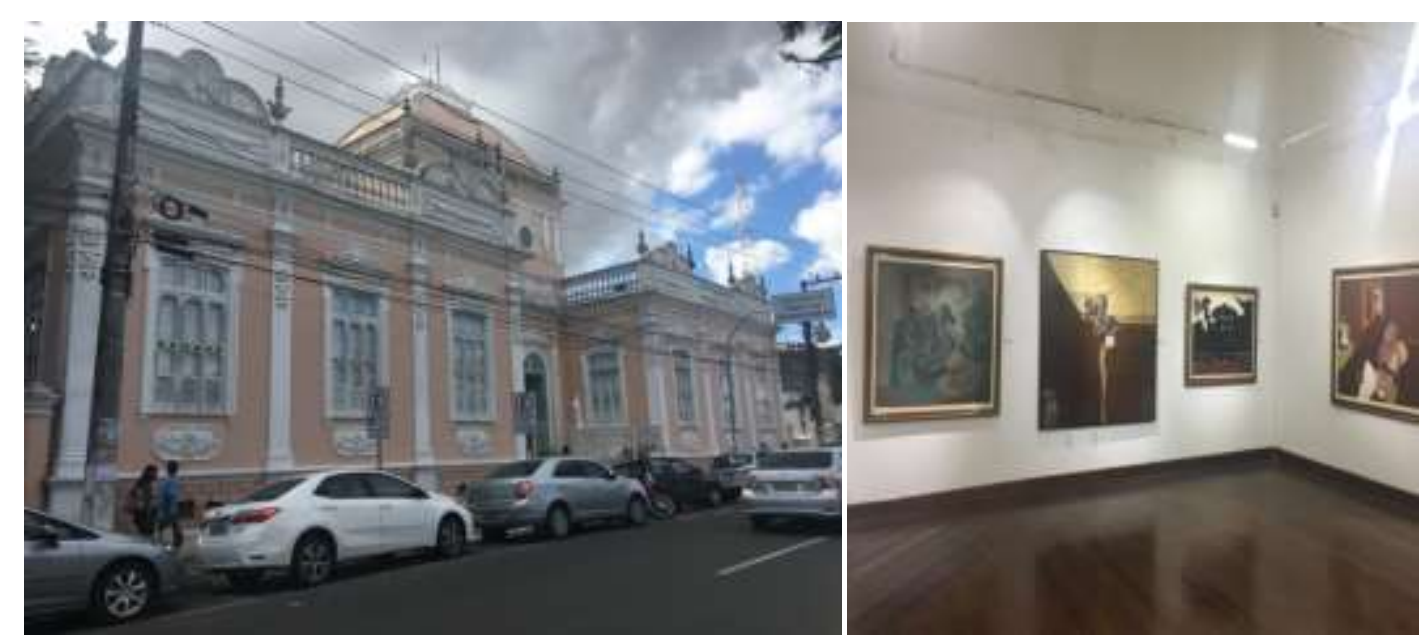

Museu Regional de Feira de Santana/ BA - 2017

(Acervo do Autor)

\section{BIBLIOGRAFIA}

ALMEIDA, Paulo Mendes (1961): "De Anita ao museu". São Paulo: Conselho Estadual de Cultura, 1961.

ARAÚJO, George Zeidan (2012): "Paulo Prado e Martínez Estrada: a tristeza como elemento definidor da brasilidade e da argentinidade". Em: Revista espaço Acadêmico, № 128, pág.118-125.

BARROS, Regina Teixeira de (2002): "Revisão de uma História: A Criação do Museu de Arte Moderna de São Paulo, 1946-1949”, dissertação de mestrado apresentada na Escola de Comunicação e Artes - ECA USP.

BIVAR, Antonio (2004): "Yolanda". São Paulo: Ed. Girafa. 
BOSI, Alfredo (1973): "O Movimento Modernista de Mário de Andrade". Em: Colóquio/Letras, n², Lisboa: Fundação C. Gulbenkian.

BULCÃO, Clóvis (2015): "Os Guinle: A história de uma dinastia". Rio de Janeiro: Ed. Intrínseca.

CAPELATO, Maria Helena Rolim (1997): "Propaganda política no varguismo e peronismo". Tese de Livre Docência, São Paulo, FFLCH-USP.

CAMARGOS, Márcia (2001): "Villa Kyrial: Crônica da Belle Époque Paulistana". São Paulo: Senac.

D`AVILA, Luiz Felipe (2004): "Dona Veridiana: a trajetória de uma dinastia paulista". São Paulo: A Girafa.

DEAN, Warren (1996):. "A Ferro e Fogo: A história e a devastação da mata Atlântica brasileira". São Paulo: Cia das Letras.

DUTRA, Eliana de Freitas (2000): "O Não ser e o ser outro. Paulo Prado e seu retrato do Brasil". Em: Revista de Estudos Históricos, №26, pág. 233-252.

DURAND, José Carlos (2010): "Arte, privilégio e distinção - arquitetura, artes plásticas e classe dirigente no Brasil 1855-1985". São Paulo, Editora Perspectiva.

FARIA, João Roberto; ARÊAS, Vilma; AGUIAR, Flávio (1997): "Décio de Almeida Prado: Um homem de Teatro". São Paulo: Edusp.

FERNANDES, Florestan (2005): "A Revolução Burguesa do Brasil". São Paulo: Editora Globo. (2008): "Mudanças Sociais no Brasil". São Paulo: Global, 2008.

FIGUEROA, Silvia Fernanda de Mendonça (1987): "Modernos Bandeirantes: a Comissão Geográfica e Geológica de São Paulo e a exploração científica do território paulista (1886-1931)", dissertação de mestrado apresentada a Faculdade de Filosofia, Letras e Ciências Humanas - FFLCH USP.

FORTE, Graziela Naclério (2010): "Entre os Salões e a Institucionalização da Arte". Em: Revista de História, Nº162, pág. 271-294.

HOMEM, Maria Cecília Naclério (1980): "História dos Bairros de São Paulo, Higienópolis, Grandeza de um bairro Paulistano". São Paulo: PMSP. 
KANTOR, Iris/ MACIEL, Débora A./ SIMÕES, Júlio A (2001): "A Escola Livre de Sociologia e Política, Anos de formação 1933-1953: Depoimentos". São Paulo: Escuta.

LAMPAZZI, Ulisses Pinheiro (2012): "Em busca do Império: A trajetória intelectual e política de Eduardo Prado", dissertação de mestrado apresentada no Programa de Pós-Graduação em História - UNESP - Franca.

LEVI, Erville Darrel (1977): "A Família Prado". São Paulo: Cultura 70.

LOURENÇO, Maria Cecília França (1999): "Museus Acolhem Moderno". São Paulo: Edusp.

MANTOAN, Marcos J (2015): "Yolanda Penteado: Gestão Dedicada à Arte Moderna", tese de doutorado apresentada na Escola de Comunicações e Artes - ECA USP.

MICELI, Sérgio (2003): "Nacional estrangeiro". São Paulo: Companhia das Letras.

MORAIS, Fernando (2011): Chatô: O Rei do Brasil. São Paulo: Cia das Letras.

MORAES, Julio Lucchesi (2013): "São Paulo, Capital Artística: a cafeicultura e as artes na Belle Époque (1906-1922)". Rio de Janeiro: Beco do Azougue.

OLIVEIRA, Cecília Helena de Salles (2003): "Museu Paulista: espaço de evocação do passado e reflexão sobre a história". Em: Anais do Museu Paulista, No10, pág.105126.

(2017): "O Museu Paulista e a gestão de Afonso Taunay: Escrita da história e historiografia, séculos XIX e XX". São Paulo: Museu Paulista da USP, 2017.

PENTEADO, Yolanda (1976): "Tudo em Cor-de-Rosa". Rio de Janeiro: Nova Fronteira. PERSIANI, Adriana (2012): "Albert Löfgren: resgate, sistematização e atualidade do pensamento de um pioneiro nos campos de climatologia, fitogeografia e conservação da natureza no Brasil", dissertação de mestrado apresentada ao Departamento de Geografia - USP.

PIVA, Carolina Brandão (2009): "Paulo Prado: Cafeicultura, Modernismo e Política", dissertação de mestrado apresentada na Faculdade de História - FU UFGO.

SAES, Flávio A. M. (2002): "Estradas de Ferro e Diversificação da Atividade Econômica na Expansão Cafeeira em São Paulo, 1870-1900". Em: ZMRECSÁNYI, Tamás/ LAPA, José R. do Amaral( $1^{\text {a ed }}$ ): História Econômica da Independência e do Império. São Paulo: Edusp e Imprensa Oficial do Estado de São Paulo, pág. p.177-191.

SEVCENKO, Nicolau (2002): "Orfeu extático na metrópole - São Paulo, sociedade e cultura nos frementes anos 20". São Paulo, Companhia das Letras. 
TOLEDO, Roberto P. de (2012): "A Capital da Solidão:Uma história de São Paulo das origens a 1900". Rio de Janeiro: Objetiva.

TOTA, Antonio Pedro (2000): "O imperialismo sedutor - a americanização do Brasil na época da Segunda Guerra". São Paulo, Companhia das Letras. 